\title{
AIR QUALITY DYNAMICS IN THE RESIDENTIAL AREA NEIGHBORING THE ZOBOR HILL FOREST IN NITRA CITY, SLOVAKIA (CASE STUDY)
}

\author{
Zuzana Pucherová, Anna Tirpáková, Dagmar Markechová ${ }^{\dagger}$
}

\begin{abstract}
Currently, mainly in urbanized environments, air is usually mentioned about air pollution. This case study is to present the results of $\mathrm{SO}_{2}$ and $\mathrm{PM}_{10}$ air quality measurements, which were carried out in selected locality - Zobor, Nitra (Slovakia) on random days in the year 2013. These data were supplemented by measurements of selected meteorological indicators. The results of statistical analysis in software STATISTICA 9 proved that average quantity of $\mathrm{SO}_{2}$ and $\mathrm{PM}_{10}$ in air are significantly varied based on monitored season (spring, summer, and winter) and day-time and night-time too. The three-factor analysis of variance ultimately proved that monitored meteorological indicators have statistically significant impact on average concentration of polluting substances in air.
\end{abstract}

Keywords: air quality, sulphur dioxide $\left(\mathrm{SO}_{2}\right)$, particulate matter $\left(\mathrm{PM}_{10}\right)$, residential area, Nitra - Zobor

\section{Introduction}

Quality of air significantly influences not only environment of human in relation to his health, but also all living organisms and individual ecosystems in terms of their existence. Substances which have degrading effect on air quality are called exhalants or polluting compounds. Level of air pollution is given by concentration of individual polluting substances in the air or its deposition on earth surface in given time.

Air pollution is a chemical, physical or biological agent that modifies the natural characteristics of the atmosphere. The harmful chemical compounds (from burning) released into the atmosphere are for example carbon monoxide (CO), nitrogen oxides $\left(\mathrm{NO}_{2}\right)$, sulphur dioxide $\left(\mathrm{SO}_{2}\right)$ and particulate matter or airborne dust (PM) and carbon dioxide $\left(\mathrm{CO}_{2}\right)$ as the most significant greenhouse effect gas. Among many sources of air pollution, one can count factories, industries, domestic heating, transportation and power plants. In urban areas, heating and transportation are the dominant factors (Gümrükçüoğlu, 2011). The causes of air pollution episodes include various factors, e.g., emissions, local and synoptic-scale meteorological conditions, topography and atmospheric chemical processes. The relative importance of such factors is dependent on the geographical region, its surrounding emission source areas and the related climatic characteristics, as well 
as the season of the year (Piringer, Kukkonen, 2002). Particulate pollution is currently the focus of air quality management and health protection policies due to its multiple impacts on human health and the environment (Bardouki et al., 2003). The air pollution in urban areas has different characteristics because of the changing meteorological factors depending on the geographical and topographical peculiarities of the urban area. The level of the air pollution concentrations is correlated with the combination of the various meteorological factors. For that reason, air pollution concentrations and meteorological data should be evaluated statistically in order to correlate them (Cuhadaroglu, Demirci, 1997). Pollutant concentrations are known to vary on all temporal scales: diurnal, day-of-week, synoptic, intraseasonal, seasonal, interannual, and short- and long-term trends resulting from imposition of control strategies (Whiteman et al., 2014). Problems of $\mathrm{PM}_{10}$ especially from traffic are evaluated or assessed in many European cities. The air pollution from the traffic in relation to the urbanized environment are subject of many studies e.g. Quitta et al. (2012), Clougherty et al. (2008), etc.

The main objective of our case study was to record seasonal and daily dynamics of $\mathrm{SO}_{2}$ and $\mathrm{PM}_{10}$ in the residential area of Nitra - Zobor, and relate them to the development of local microclimatic parameters.

\section{Materials and Methods}

Our research comes from the execution of the project and from measuring of air quality within the months of the year 2012 in urbanized area of Nitra. This research was conducted only within hourly measurements over the course of each day-time, however in six different locations in the city. We measured several meteorological indicators and air quality indicators and all measured indicators are evaluated in the research publication (Rózová et al., 2013). Within the hourly measurements of pollutant changes throughout the year the most distinctly visible were the changes in concentration of $\mathrm{SO}_{2}$ and $\mathrm{PM}_{10} . \mathrm{SO}_{2}$ was measured in higher concentrations in winter (in the heating season) than in the summer months and $\mathrm{PM}_{10}$ was measured in lower values from spring to autumn. Simultaneously we were interested whether there would be changes in concentrations of $\mathrm{SO}_{2}$ and $\mathrm{PM}_{10}$ during the day-time and night-time.

Therefore, during the year 2013 the measurements of these pollutants were recorded only at one selected location, however both day-time and night-time. During spring, summer and winter season 2013 we carried out measurements of air quality in selected location of Nitra, observing concentration of $\mathrm{SO}_{2}$ and $\mathrm{PM}_{10}$. In our case study, we considered the most important comparison of the summer and winter seasons, but statistically meaningful results also showed in the spring measurement. For this reason, we have included the spring season in the results, but we did not include the autumn 2013. At the same time the meteorological parameters were observed: direction and speed of wind, atmospheric pressure, 
temperature and relative humidity of air. Measurements of air quality was carried out in selected location (in individual built-up area) in the town of Nitra (Zobor neighborhood, coordinates: $48.3352778 \mathrm{~N}, 18.0911111 \mathrm{E}$ ) in three seasons of the year 2013 (spring, summer and winter). Measurements of air quality in the year 2013 were carried out on random days during mentioned seasons. For our statistical analyses we considered the daily part of the day between 06.00-22.00 and the night part of the day from 22.00 to 06.00. The total length of each continuous three-day measurement was 72 hours. For this case study, we randomly selected 3 parts of 2013: 27th - 30th March, 2nd - 4th August and 29th - 31st December. In each season of our measurements, we had most likely experienced extreme weather: temperatures below $0^{\circ} \mathrm{C}$ and snow in March, high temperatures, above $35^{\circ} \mathrm{C}$ in August, and temperatures above $10^{\circ} \mathrm{C}$ in December.

For detecting content of $\mathrm{SO}_{2}$ in air we used portable multicomponent device Aeroqual AQM60 Environmental Station (Aeroqual Ltd., 109 Valley Road, Mt Eden, Auckland 1024, New Zealand), which measures content of several essential polluting compounds $\left(\mathrm{SO}_{2}, \mathrm{NOx}, \mathrm{CO}, \mathrm{CO}_{2}, \mathrm{VOC}\right)$ and thanks to climate converter (Vaisala Weather Transmitter WXT520, Vaisala Oyj, Helsinki, P. O. Box 26, Finland) certain meteorological indicators as well (direction and speed of wind, atmospheric pressure, temperature and relative humidity - location of the sensor thanks to a pedestal and a metal rod at a height of $2.5 \mathrm{~m}$ above the ground). The content of polluting compounds was measured in ppm (parts per million). Gas module for sulphur dioxide performs measurements with accuracy $< \pm 0.5 \mathrm{ppm}$ and precision $0.2 \mathrm{ppm}$. Portable device DustTrak DRX model 8535 (TSI Incorporated, 500 Cardigan Road, Shoreview, MN55126-3996 USA) was used for measuring airborne dust particles $\left(\mathrm{PM}_{1}, \mathrm{PM}_{2,5}, \mathrm{RESP}\right.$ - Respirable, $\mathrm{PM}_{10}$ and TPM - Total Particulate Matters). This device measures and records concentration of dust particles in air $\left(\mathrm{mg} / \mathrm{m}^{3}\right)$. DustTrak DRX measures particle sizes of polluting compounds in the range of $0.1-15 \mu \mathrm{m}$ and by weight concentration between $0.001-$ $150 \mathrm{mg} / \mathrm{m}^{3}$ with separation $\pm 0.1 \%$ of the scan or $0.001 \mathrm{mg} / \mathrm{m}^{3}$ and with flow 3 $1 / \mathrm{min}^{1}$. Since we did not compare the pollutants with each other, we keep the measured values in the original units.

The results of measurements were evaluated by methods of mathematical statistics; the calculations themselves were executed in software STATISTICA 9. We have decided to statistically evaluate the results of the measurements by the two-phase and three-factor analysis of scattering (Anděl, 2003). During statistical analysis of results, we used the two-factor analysis of variance with interactions. Factor $A$ was the season of the year, during which the measurements were carried out and factor $B$ was the time of the day-time of the monitoring. Factor $A$ had 3 levels (spring, summer, winter) and factor $B$ had 2 levels (day-time, night-time). In a standard way, all observed values $\left(\mathrm{SO}_{2}, \mathrm{PM}_{10}\right)$ have been denoted by $X$. In the following step, we were interested, which levels of factor $A$ are statistically significantly distinct in observed index. For testing distinction, we used the Tukey 
test multi-comparison of averages. The result of the evaluation is that the correlation matrices are between the two observed signs and we did not combine them.

Another problem we faced in our research with method ANOVA was the question, whether speed and direction of wind have an effect on the value of polluting compounds in the air. For solving this problem, we used two-factor analysis of variance without interaction. We verified the impact of two factors $C, D$ on values of the observed variable $X$, while the factor $C$ was the speed of wind and factor $D$ was the direction of wind. The observed variable $X$ was the amount of polluting compound in the air $\left(\mathrm{SO}_{2}\right.$ and $\left.\mathrm{PM}_{10}\right)$. The factor $C$ (the speed of wind) had 5 levels - intervals A to $\mathrm{E}$ in $\mathrm{m} / \mathrm{s}^{1}$ (A: 0.120-3.896; B: 3.897-7.673; C: 7.67411.450; D: $11.451-15.227$; E: $15.228-19.004$ ) and the factor $D$ (the direction of wind) had 8 levels in degrees (N: 0-22.5; NE: 22.6-67.5; E: 67.6-112.5; SE: 112.6-157.5; S: 157.6-202.5; SW: 202.6-247.5; W: 247.6-292.5; NW: 292.6$337.5 ; \mathrm{N}: 337.6-360)$. We divided the wind rose into 8 regular intervals - each of them presenting 44.9 degrees of the wind direction (for $\mathrm{N}$ wind direction there are two intervals with joint value of 44.9 degrees).

Lastly, we verified the effect of temperature, relative humidity and air pressure on the value of polluting compounds in the air $\left(\mathrm{SO}_{2}\right.$ and $\left.\mathrm{PM}_{10}\right)$. Threefactor analysis of variance without interactions was used to test the statistical significance of the effect of these three factors. The factor $E$ was the temperature, the factor $F$ was the relative humidity and the factor $G$ was the air pressure. The measured values of each considered factor were divided into 5 levels. The temperature $\left({ }^{\circ} \mathrm{C}\right)$ had these 5 levels: A: -1.9-5.78; B: 5.781-13.461; C: $13.462-$ 21.142; D: 21.143-28.823; E: 28.824-36.504, the relative humidity (\%) had these 5 levels: A: 21.8-36.0; B: 36.01-50.21; C: 50.22-64.42; D: 64.43-78.63; E: 78.64-92.84 and the pressure $(\mathrm{kPa})$ had 5 levels too: A: 976.9-981.2; B: 981.21985.51; C: 985.52-989.82; D: 989.83-994.13; E: 994.14-998.44. We didn't take into account of frequency distribution in the divided 5 or 8 intervals in the statistical analysis.

The subject of further analysis is the testing of differences. In the following step, we were interested in which levels of factor $C-G$ are significantly different in the observed variable $\left(\mathrm{SO}_{2}\right.$ and $\left.\mathrm{PM}_{10}\right)$. We used the Tukey test of multicomparison of averages to test the differences.

\section{Results}

We verified whether the effect of mentioned factors is statistically significant in relation to the value of polluting compounds in air. The observed variable $X$ was the amount of $\mathrm{SO}_{2}$ or $\mathrm{PM}_{10}$ in air. Analysis of variance was gradually carried out for individual polluting compounds $\mathrm{SO}_{2}$ and $\mathrm{PM}_{10}$. Results of the two-factor analysis of variance are given in the Table 1. As in all cases the 
value of probability is $p=0.000000$, we reject the null hypothesis at arbitrarily small significance level. Probability of error which we commit this way is close to zero. That means that the average value of polluting compounds $\left(\mathrm{SO}_{2}\right.$ and $\left.\mathrm{PM}_{10}\right)$ in the air during the observed seasons is different and the average value of polluting $\left(\mathrm{SO}_{2}\right.$ and $\left.\mathrm{PM}_{10}\right)$ in the air is not the same during day-time and night-time. The mutual interaction of factors $A, B$ in relation to amount of $\mathrm{SO}_{2}$ and $\mathrm{PM}_{10}$ in air is statistically significant. The results which we obtained using the Tukey test, were evaluated based on calculated $p$-values, which are distinctly given in Table 2 . Based on the results in this table we can conclude that the measured average values of $\mathrm{SO}_{2}$ and $\mathrm{PM}_{10}$ are statistically significantly different during all observed seasons. The results are graphically illustrated in Graph 1 and 2 (Vertical bars denote 0.95 confidence intervals).

Table 1: The final table of double classification analysis of variance with interactions for the measured value of $\mathrm{SO}_{2}$ and $\mathrm{PM}_{10}$ in the air

\begin{tabular}{|l|c|c|c|c|}
\hline Effect & $\boldsymbol{S S}$ & $\boldsymbol{D} \boldsymbol{f}$ & $\boldsymbol{M S}$ & $\boldsymbol{F}$ \\
\hline Season $\mathrm{SO}_{2}$ & 0.07 & 2 & 0.04 & $47.38^{* * *}$ \\
\hline Time during day $\mathrm{SO}_{2}$ & 0.04 & 1 & 0.04 & $50.63^{* * *}$ \\
\hline Season* Time during day $\mathrm{SO}_{2}$ & 0.14 & 2 & 0.07 & $93.91^{* * *}$ \\
\hline Season $\mathrm{PM}_{10}$ & 6.74 & 2 & 3.37 & $4102.65^{* * *}$ \\
\hline Time during day $\mathrm{PM}_{10}$ & 0.26 & 1 & 0.26 & $320.08^{* * *}$ \\
\hline Season * Time during day $\mathrm{PM}_{10}$ & 0.18 & 2 & 0.09 & $109.02 * * *$ \\
\hline
\end{tabular}

( $S S$ - sums of squares deviations, $D f$ - degrees of freedom, $M S$ - dispersions, $F$ values of the test criteria, $p$ - values of probability, $* * * p<0.001$ )

Table 2: The results of Tukey's test of contrasts effects of factor $A$ on $\mathrm{SO}_{2}$ and factor $A$ on $\mathrm{PM}_{10}$ content in the air in different seasons in 2013

\begin{tabular}{|l|c|c|c|}
\hline Season & Spring monitoring & SM & WM \\
\hline Average $\mathrm{SO}_{2}$ & 0.01377 & 0.01015 & 0.01899 \\
\hline $\mathrm{SM} \mathrm{SO}_{2}$ & $0.00006^{* * *}$ & & \\
\hline $\mathrm{WM} \mathrm{SO}_{2}$ & $0.00002^{* * *}$ & $0.00002^{* * *}$ & \\
\hline Average $\mathrm{PM}_{10}$ & 0.07973 & 0.02156 & 0.09909 \\
\hline $\mathrm{SM} \mathrm{PM}_{10}$ & $0.00002^{* * *}$ & & \\
\hline $\mathrm{WMPM}_{10}$ & $0.00002^{* * *}$ & $0.00002 * * *$ & \\
\hline
\end{tabular}

(SM - summer monitoring, WM - winter monitoring, $p$ - values of probability, $* * * p<0.001)$

By testing it was proved that the amount of measured values of polluting compounds $\mathrm{SO}_{2}$ and $\mathrm{PM}_{10}$ during particular seasons is significantly different. This matter of fact can be caused by transforming meteorological indicators, mainly temperature, pressure, humidity and speed and direction of wind. The average 
values of amount of $\mathrm{SO}_{2}$ and $\mathrm{PM}_{10}$ in the air during day-time and night-time are illustrated in Graph 3 and 4 (Vertical bars denote 0.95 confidence intervals).

Graph 1: The average values of $\mathrm{SO}_{2}$ (ppm) in the air in different seasons of measurements in 2013

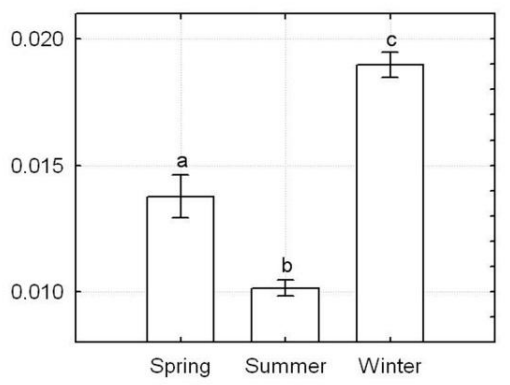

Graph 3: The average values of $\mathrm{SO}_{2}$ (ppm) in the air during day-time and night-time in different seasons of measurements in 2013

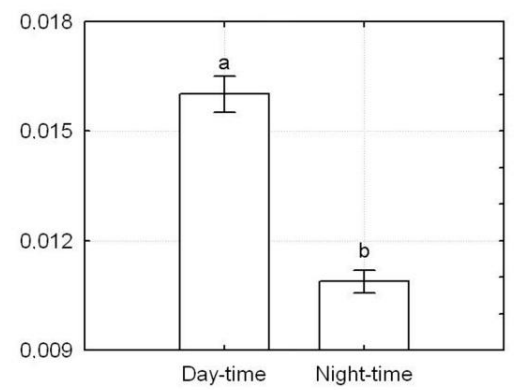

Graph 2: The average values of $\mathrm{PM}_{10}$ $\left(\mathrm{mg} / \mathrm{m}^{3}\right)$ in the air in different seasons of measurements in 2013

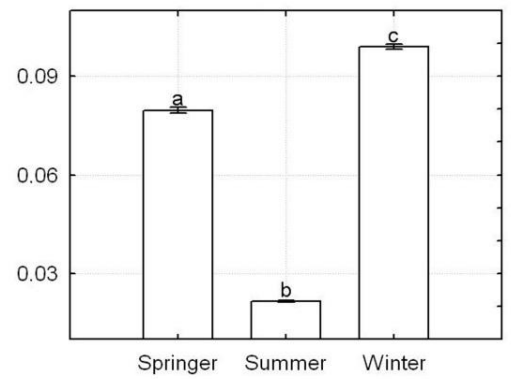

Graph 4: The average values of $\mathrm{PM}_{10}$ $\left(\mathrm{mg} / \mathrm{m}^{3}\right)$ in the air during day-time and night-time in different seasons of measurements in 2013

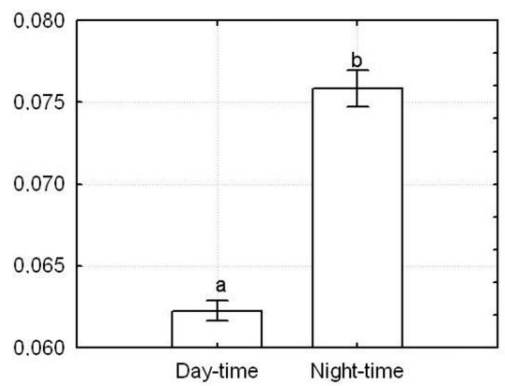

With method ANOVA, we verified whether the effect of the presented factors on the value of polluting compounds in the air is statistically significant. The results which we obtained using the two-factor analysis of variance with repetition for each observed attribute (amount of $\mathrm{SO}_{2}$ and amount of $\mathrm{PM}_{10}$ ), are distinctly noted in Table 3 .

In this case, we also evaluated the results based on the calculated values of probability $p$. As in all cases the value of probability $\mathrm{p}$ is low enough, we can reject the tested hypotheses on the relevant level of significance. This proved that the speed of wind and direction of wind statistically significantly influence the amount of $\mathrm{SO}_{2}$ and $\mathrm{PM}_{10}$ in the air. 
Table 3: The final table of double classification analysis of variance for measured value of $\mathrm{SO}_{2}$ and $\mathrm{PM}_{10}$ in the air

\begin{tabular}{|l|c|c|c|c|}
\hline $\mathbf{S O}_{2} / \mathbf{P M}_{10}$ & $\boldsymbol{S S}$ & $\boldsymbol{D} \boldsymbol{f}$ & $\boldsymbol{M S}$ & $\boldsymbol{F}$ \\
\hline Wind speed $\mathrm{SO}_{2}$ & 0.01 & 4 & 0.003 & $3.32^{*}$ \\
\hline Wind speed $\mathrm{PM}_{10}$ & 0.05 & 4 & 0.012 & $6.43^{* * *}$ \\
\hline Wind direction $\mathrm{SO}_{2}$ & 0.16 & 7 & 0.023 & $29.69^{* * *}$ \\
\hline Wind direction $\mathrm{PM}_{10}$ & 0.79 & 7 & 0.113 & $61.16^{* * *}$ \\
\hline
\end{tabular}

( $S S$ - sums of squares deviations, $D f$ - degrees of freedom, $M S$ - dispersions, $F$ values of the test criteria, $p$ - values of probability, $* p<0.05$; ***p $<0.001$ )

The Tukey test was evaluated based on calculated $p$-values. Based on the results in these tables we can conclude that the average values of $\mathrm{SO}_{2}$ and $\mathrm{PM}_{10}$ in the air are statistically significantly different in relation to speed of wind in the interval A $\left(0,120-3,896 \mathrm{~m} / \mathrm{s}^{1}\right)$ and in the interval B $\left(3,897-7,673 \mathrm{~m} / \mathrm{s}^{1}\right)$. A statistically significant difference of the amount of $\mathrm{SO}_{2}$ and $\mathrm{PM}_{10}$ in the air was not proved in other intervals of the speed of wind. The above results are graphically illustrated in the Graph 5 and 6 (Vertical bars denote 0.95 confidence intervals).

Graph 5: The average values of $\mathrm{SO}_{2}$ $(\mathrm{ppm})$ in the air in each category wind speed (factor $C$ )

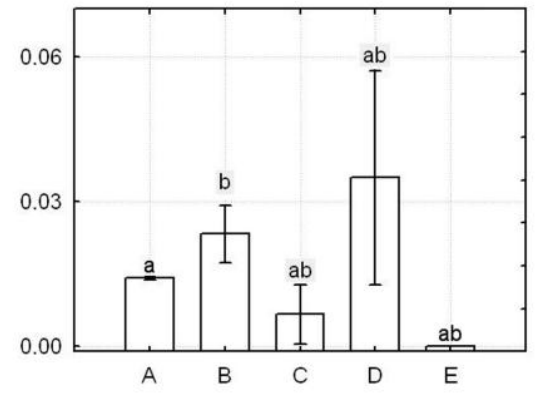

Graph 6: The average values of $\mathrm{PM}_{10}$ $\left(\mathrm{mg} / \mathrm{m}^{3}\right)$ in the air in each category wind speed (factor $C$ )

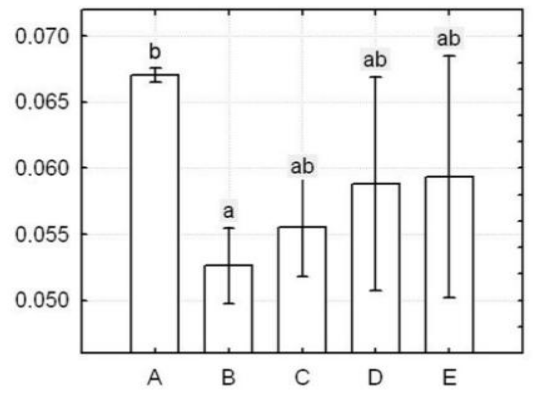

Next, we were interested to find out which levels of factor $D$ (direction of wind) are statistically significantly different in terms of the observed attribute. Calculated $p$-values for individual polluting compounds $\left(\mathrm{SO}_{2}\right.$ and $\left.\mathrm{PM}_{10}\right)$ are given in the Graph 7 and 8 (Vertical bars denote 0.95 confidence intervals). We proceeded analogically in determining the effect of factor $D$ (direction of wind) on the amount of polluting compounds in the air, i.e. $\mathrm{SO}_{2}$ and $\mathrm{PM}_{10}$. The average values of $\mathrm{SO}_{2}$ in air are statistically different in the case of the direction of wind from North to Northeast, East, Southeast, also equally statistically different 
directions of wind from Northeast and East to South, Southwest, West, Northwest, also from Southeast to South, West, Southwest, and finally from Southwest to West and Northwest. In other directions of wind there was no statistically proven significant difference of the amount of $\mathrm{SO}_{2}$ in the air.

The average values of $\mathrm{PM}_{10}$ in air are statistically different in the case of the direction of wind from North to Northeast, Southeast, South, Southwest, next from Northeast to Southeast, South, Southwest, West, also from East to Southeast, South, Southwest, also from Southeast to South, Southwest, West, Northwest, and equally statistically different directions of wind from South and Southwest to West and Northwest. In other directions of wind there was no statistically proven significant difference of the amount of $\mathrm{PM}_{10}$ in the air.

Graph 7: The average values of $\mathrm{SO}_{2}$ (ppm) in the air at different wind directions



Graph 8: The average values of $\mathrm{PM}_{10}$ $\left(\mathrm{mg} / \mathrm{m}^{3}\right)$ in the air at different wind directions

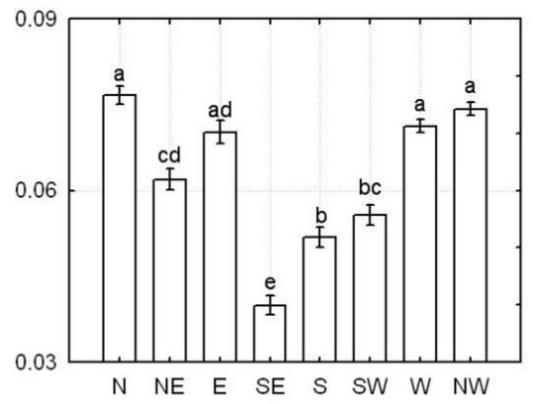

We tested three hypotheses, where the first is the hypothesis that the average temperature does not have an effect on the amount of polluting compounds in the air $\left(\mathrm{SO}_{2}\right.$ and $\left.\mathrm{PM}_{10}\right)$, the second is the hypothesis that the relative humidity does not have an effect on the amount of polluting compounds in the air $\left(\mathrm{SO}_{2}\right.$ and $\mathrm{PM}_{10}$ ) and the third is the hypothesis that the air pressure does not have an effect on the amount of polluting compounds in the air $\left(\mathrm{SO}_{2}\right.$ and $\left.\mathrm{PM}_{10}\right)$. After entering the initial data, we obtained the following output table (Table 4) of the three-factor analysis of variance. As in all cases the value of probability $\mathrm{p}$ is low enough, these three tested hypotheses can be rejected on the relevant level of significance. By testing it was proved that the pressure, temperature and also air humidity statistically significantly influence the value of polluting compounds $\mathrm{SO}_{2}$ and $\mathrm{PM}_{10}$ in the air.

With the help of Tukey's test of differences of effect of the factor $E$ it was proved that there is no statistically significant difference in the average value of $\mathrm{SO}_{2}$ in air in two cases; between temperatures in the intervals $\mathrm{A}\left(-1.90-5.78{ }^{\circ} \mathrm{C}\right)$ 
and $\mathrm{C}\left(13.460-21.142{ }^{\circ} \mathrm{C}\right)$ and in intervals $\mathrm{E}\left(28.824-36.504{ }^{\circ} \mathrm{C}\right)$ and $\mathrm{D}(21.143-$ $28.823{ }^{\circ} \mathrm{C}$ ). In other cases, differences in concentration of $\mathrm{SO}_{2}$ are statistically significant. A statistically significant difference in the average value of $\mathrm{SO}_{2}$ in air was proved in every category of the relative humidity (factor $F$ ) and air pressure also (factor $G$ ). The results are graphically illustrated in Graphs 9-11 (Vertical bars denote 0.95 confidence intervals).

Table 4: The final table of triple classification analysis of variance for measured value of $\mathrm{SO}_{2}$ and $\mathrm{PM}_{10}$ in the air

\begin{tabular}{|l|c|c|c|c|}
\hline $\mathbf{S O}_{2} / \mathbf{P M}_{10}$ & $\boldsymbol{S S}$ & $\boldsymbol{D f}$ & $\boldsymbol{M S}$ & $\boldsymbol{F}$ \\
\hline Pressure $\mathrm{SO}_{2}$ & 0.38 & 4 & 0.094 & $132.84 * * *$ \\
\hline Temperature $\mathrm{SO}_{2}$ & 0.01 & 4 & 0.004 & $5.11 * * *$ \\
\hline Humidity $\mathrm{SO}_{2}$ & 0.04 & 4 & 0.010 & $14.31 * * *$ \\
\hline Pressure $\mathrm{PM}_{10}$ & 1.62 & 4 & 0.405 & $761.71 * * *$ \\
\hline Temperature $\mathrm{PM}_{10}$ & 2.42 & 4 & 0.606 & $1140.02 * * *$ \\
\hline Humidity $\mathrm{PM}_{10}$ & 0.60 & 4 & 0.150 & $283.01 * * *$ \\
\hline
\end{tabular}

( $S S$ - sums of squares deviations, $D f$ - degrees of freedom, $M S$ - dispersions, $F$ values of the test criteria, $p$ - values of probability, ${ }^{* * *} p<0.001$ )

Graph 9: The average values of $\mathrm{SO}_{2}$ $(\mathrm{ppm})$ in the air in each category of air temperature (factor $E$ )



Graph 10: The average values of $\mathrm{SO}_{2}$ $(\mathrm{ppm})$ in the air in each category of relative humidity (factor $F$ )

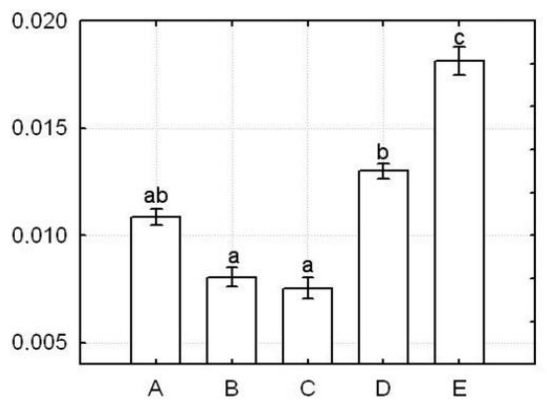

Based on the results in the Graph 12, in the case of factor $E$ we can conclude that the average value of $\mathrm{PM}_{10}$ in air is statistically significantly different almost in every category. A statistically significant difference in the average value of $\mathrm{PM}_{10}$ in air was not proved only in one case; between temperatures in the intervals $\mathrm{E}\left(28.824-36.504{ }^{\circ} \mathrm{C}\right)$ and $\mathrm{C}\left(13.46-21.142{ }^{\circ} \mathrm{C}\right)$. A statistically significant difference in the average value of $\mathrm{PM}_{10}$ in air was proved in all cases of relative humidity (Graph 13). Results of Tukey's test (Graph 14) proved the differences in average value of $\mathrm{PM}_{10}$ in the air almost in every category of pressure to be 
statistically significant. A statistically significant difference in the average value of $\mathrm{PM}_{10}$ in air was not proved only in one case, that being between the categories of pressure D (989.83-994.13 kPa) and E (994.14-998.44 kPa) (In graphs 12-14 are vertical bars denote 0.95 confidence intervals).

Graph 11: The average values of $\mathrm{SO}_{2}$ (ppm) in the air in each category of atmospheric pressure (factor $G$ )

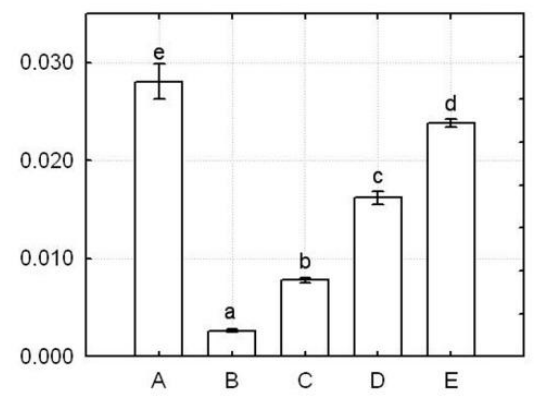

Graph 13: The average values of $\mathrm{PM}_{10}$ $\left(\mathrm{mg} / \mathrm{m}^{3}\right)$ in the air in each category of relative humidity (factor $F$ )

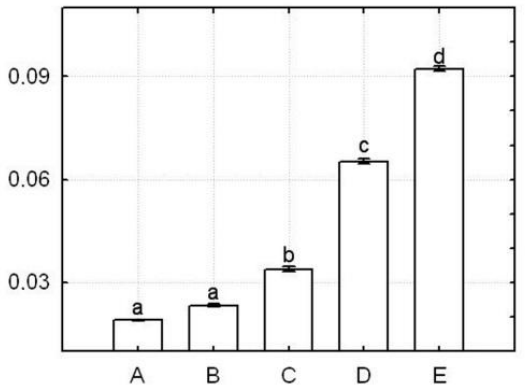

Graph 12: The average values of $\mathrm{PM}_{10}$ $\left(\mathrm{mg} / \mathrm{m}^{3}\right)$ in the air in each category of air temperature (factor $E$ )

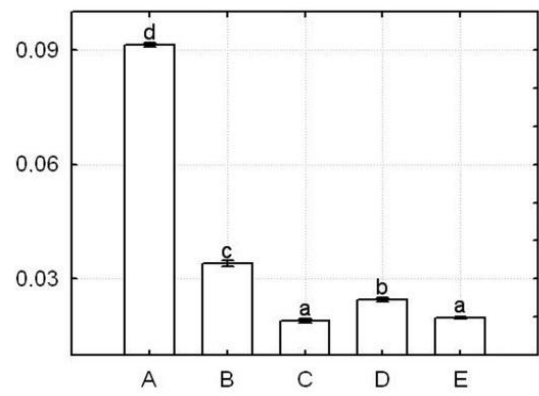

Graph 14: The average values of $\mathrm{PM}_{10}$ $\left(\mathrm{mg} / \mathrm{m}^{3}\right)$ in the air in each category of atmospheric pressure (factor $G$ )

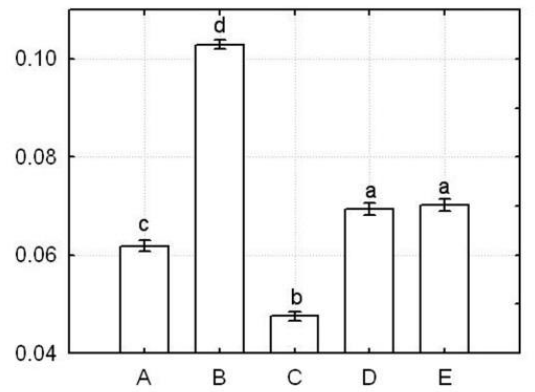

\section{Discussion}

Urbanization has a myriad of implications for the environment. More recently, the multifariousness of human effects has created various types of urban environments (De La Barrera et al., 2016). According to Nowak (1994) air pollution from transportation, industry, domestic heating, and solid urban waste incineration is a major problem for environmental quality and human health in the urban environment; it leads to increases in respiratory and cardiovascular diseases. 
Vegetation in urban systems can improve air quality by removing pollutants from the atmosphere, including ozone $\left(\mathrm{O}_{3}\right)$, sulphur dioxide $\left(\mathrm{SO}_{2}\right)$, nitrogen dioxide $\left(\mathrm{NO}_{2}\right)$, carbon monoxide $(\mathrm{CO})$ and particulate matter, which size is less than $10 \mu \mathrm{m}$ $\left(\mathrm{PM}_{10}\right)$. Limit values for individual pollutants for the protection of human health and the protection of vegetation are set out in the public notice of the Ministry of Environment SR no. 244/2016 Coll. about air quality. The hourly value for human health limit is $350 \mu \mathrm{g} / \mathrm{m}^{3}$ for $\mathrm{SO}_{2}$ and may not be exceeded more than 24 times per calendar year and the daily value of $25 \mu \mathrm{g} / \mathrm{m}^{3}$ may not be exceeded more than 3 times per calendar year. The annual limit value for the protection of vegetation is $20 \mu \mathrm{g} / \mathrm{m}^{3}$ without possible overrun during the year. $\mathrm{PM}_{10}$ have an hourly limit value for the protection of human health of $50 \mu \mathrm{g} / \mathrm{m}^{3}$, which cannot be exceeded more than 35 times a calendar year and an annual value of $40 \mu \mathrm{g} / \mathrm{m} 3$ without possible overrun in the year. For $\mathrm{SO}_{2}$, a threshold of $500 \mu \mathrm{g} / \mathrm{m}^{3}$ (average hourly value over 3 hours) and for $\mathrm{PM}_{10}$ is a valid threshold of $100 \mu \mathrm{g} / \mathrm{m}^{3}$ and a warning threshold of $150 \mu \mathrm{g} / \mathrm{m}^{3}$ (average of 12 hours).

Polluting compounds $\mathrm{SO}_{2}$ and $\mathrm{PM}_{10}$ in the air are among the key components of scoring in the ambient air situation in certain area. Both pollutants belong to the most significant pollutants of the recent decades. In our study the average daily $\mathrm{SO}_{2}$ concentration during the day-time measured was $0.016 \mathrm{ppm}$ and at night-time the average $\mathrm{SO}_{2}$ value was $0.011 \mathrm{ppm}$. Average daily $\mathrm{SO}_{2}$ values ranged from $0.008 \mathrm{ppm}$ (summer) to $0.020 \mathrm{ppm}$ (spring, winter). From our measurements, the highest average $\mathrm{SO}_{2}$ night-time value was $0.017 \mathrm{ppm}$ in the winter period, and the lowest average night-time values of $\mathrm{SO}_{2}$ were measured in spring $(0.002 \mathrm{ppm})$. The highest measured value of $\mathrm{SO}_{2}$ was on 31 December 2013 at 23:02 $(0.490 \mathrm{ppm})$ and the lowest measured value was on 2 August 2013 at 20:00 (0.001 ppm).

Similar results of measured $\mathrm{SO}_{2}$ values in the seasons (spring, summer and winter) were obtained in several studies e.g. Durran et al. (1979), Luhana et al. (2007) etc. Measured $\mathrm{SO}_{2}$ concentrations in the vicinity of point sources are highest for winter and spring conditions and lowest for summer. The major factors are among influencing the $\mathrm{SO}_{2}$ oxidation reactions in the clouds, in particular the chemical composition of air, changes in light intensity between day-time and nighttime and the influence of meteorological parameters such as humidity, wind speed and atmospheric stability.

The average $\mathrm{PM}_{10}$ values in our measurements were also diverse during the year 2013. The average day-time $\mathrm{PM}_{10}$ value was $0.062 \mathrm{mg} / \mathrm{m}^{3}$ and the average night-time value was $0.076 \mathrm{mg} / \mathrm{m}^{3}$. The average daily value of $\mathrm{PM}_{10}$ was 0.070 $\mathrm{mg} / \mathrm{m}^{3}$ in spring, $0.021 \mathrm{mg} / \mathrm{m}^{3}$ in summer and with maximum $0.095 \mathrm{mg} / \mathrm{m}^{3}$ in winter. The concentrations of night-time values of $\mathrm{PM}_{10}$ were shown likewise. The average night-time value of $\mathrm{PM}_{10}$ was $0.098 \mathrm{mg} / \mathrm{m}^{3}$ in spring, $0.022 \mathrm{mg} / \mathrm{m}^{3}$ (almost identical to the average day-time value in the same season) and highest again in winter with $0.107 \mathrm{mg} / \mathrm{m}^{3}$. The highest measured value of $\mathrm{PM}_{10}$ was on 31 
December 2013 at $20: 24\left(0.427 \mathrm{mg} / \mathrm{m}^{3}\right)$ and the lowest measured value was on 4 August 2013 at $22: 18\left(0.007 \mathrm{mg} / \mathrm{m}^{3}\right)$.

The influence of atmospheric exchange conditions on near-surface $\mathrm{PM}_{10}$ concentrations are evaluated in four cities in the South-West of Germany in the period from 2001 to 2005 (Roste et al., 2009). The results of their research point to relatively high $\mathrm{PM}_{10}$ values, especially in winter, due to the absence of precipitation during this period. The results of this statistical analysis indicate that the height of several meteorological variables (for example solar radiation, air temperature and wind speed) affects the nearest $\mathrm{PM}_{10}$ concentrations in cities. Similarly, higher $\mathrm{PM}_{10}$ values were measured in the winter months in a study that analysed and evaluated $\mathrm{PM}_{10}$ in seven selected regions within the European Union. Climatic differences and long-range transport contributed to the increase of $\mathrm{PM}_{10}$ (Querol et al., 2004). The ambient $\mathrm{PM}_{10}$ aerosol samples from Taiwan's Taichung metropolitan basin were collected between October 1997 and January 1998, and were studied their chemical characteristics (Tsai, Cheng, 2004). This research results relate to the average wind speed and relative humidity, which is likely to cause stagnation of $\mathrm{PM}_{10}$ as pollutants.

The relationship between air quality, vegetation and microclimatic factors has also been addressed by several authors. In order to mitigate air pollutant problems, the use of urban vegetation is often promoted as an effective measure to reduce concentrations. This measure is based on the underlying argument that trees (and vegetation in general) have the capability of cleaning the air by filtering out the pollutants. Vegetation leaves absorb gaseous pollutants through their stomata, while particles are removed from the air by deposition onto the leaves and the branches (Vos et al., 2013). The urban trees influence local air quality in various ways. Trees can reduce or increase building energy use by shading buildings, altering air flows and lowering air temperatures through transpiration (Heisler, 1986). Urban green spaces can provide a significant cooling service, which extends beyond the green space boundaries (Vaz Monteiro et al., 2016).

\section{Conclusion}

The results of the measurements of the $\mathrm{SO}_{2}$ and $\mathrm{PM}_{10}$ in our case study showed the differences between 3 randomly selected periods in the year and the differences between day-time and night-time. The results of the measurements prove that the amounts of polluting compounds are varied during different periods of the year. Concentrations of $\mathrm{SO}_{2}$ were highest during the winter measurement, which is probably due to heating season (winter measurement). Concentration of $\mathrm{SO}_{2}$ can get to air from sources of pollution. In urbanized areas, specifically in the area we monitored in - residential area, the source is mainly energetic burning processes in residential houses and buildings (local furnaces). The amount of measured concentration of $\mathrm{SO}_{2}$ can be also influenced by meteorological indicators, mainly changing temperature during the year. Higher levels of 
concentration of $\mathrm{SO}_{2}$ in the air were measured during the colder periods of the year. On the contrary during the warmer periods of the year, the concentration of $\mathrm{SO}_{2}$ was lower. Also thanks to relation between speed and direction of wind, it is possible for $\mathrm{SO}_{2}$ to be spread from even remote areas into relatively clean areas.

We measured in our case study lower concentration of $\mathrm{PM}_{10}$ during the summer measurement. We presume, that is due to retaining of the dust particles with assimilatory organs. In case of $\mathrm{PM}_{10}$, tree vegetation in the monitored area can be an important factor - lower concentration of dust particles was measured during the phase of foliage in the summer season. In the winter, with the microclimatic conditions, with the use of spreading bulk material in the streets and with local heating, higher $\mathrm{PM}_{10}$ values were measured.

In the statistical analysis of the results of measurements of pollutants in the atmosphere in selected location in Nitra we used selected methods of mathematical statistics - specifically two-factor and three-factor analysis of variance with interactions. As already stated, the results of statistical analysis proved that average quantity of $\mathrm{SO}_{2}$ and $\mathrm{PM}_{10}$ in the air significantly varies based on monitored season (spring, summer and winter). It has been shown that the seasons have a statistically significant impact on the concentration of pollutants in the air. At the same time, the statistical analysis revealed that the differences between day-time and nighttime were statistically significant.

\section{Acknowledgement}

Contribution was elaborated with support of Grant agencies of MESRS of the Slovak republic within the project KEGA No. 032UKF-4/2018 Overview of Methods and Proposal for the Application of the Ecosystem Services Concept in the Environmental Studies Study Program. Special acknowledgement is for our coauthor prof. RNDr. Dagmar Markechová, CSc., which left us on February 15, 2019.

\section{References}

ANDĚL, J. 2003. Statistical methods. [Statistické metody]. Praha : Univerzita Karlova, MATFYZPRESS, 2003. 299 p. ISBN 80-86732-08-8.

BARDOUKI, H. - LIAKAKOU, H. - ECONOMOU, C. - SCIARE, J. SMOLÍK, J. - ŽDÍMAL, V. - ELEFTHERIADIS, K. - LAZARIDIS, M. DYE, C. - MIHALOPOULOS, N. 2003. Chemical composition of sizeresolved atmospheric aerosols in the eastern Mediterranean during summer and winter. In Atmospheric Environment. ISSN 1352-2310, 2003, vol. 37, no. 2, pp. 195-208.

CLOUGHERTY, J. E. - WRIGHT, R. - BAXTER, L. K. - LEVY, J. I. 2008. Land use regression modelling of intra-urban residential variability in multiple 
traffic-related air pollutants. In Environmental Health [online]. ISSN 1476069X, 2008, vol. 17, no. 7, pp. 1-14.

CUHADAROGLU, B. - DEMIRCI, E. 1997. Influence of some meteorological factors on air pollution in Trabzon city. In Energy and Buildings. ISSN 03787788, 1997, vol. 25, no. 3, pp. 179-184.

DE LA BARRERA, F. - RUBIO, P. - BANZHAF, E. 2016. The value of vegetation cover for ecosystem services in the suburban context. In Urban Forestry \& Urban Greening. ISSN 1618-8667, 2016, vol. 16, pp. 110-122.

DURRAN, D. R. - MELDGIN, M. J. - LIU, M. K. - THOEM, T. HENDERSON, D. 1979. A study of long range air pollution problems related to coal development in the Northern Great Plains. In Atmospheric Environment. ISSN 1352-2310, 1979, vol. 13, no. 7, pp. 1021-1037.

GÜMRÜKÇÜOĞLU, M. 2011. Urban air pollution monitoring by using geographic information systems: a case study from Sakarya, Turkey. In Carpathian Journal of Earth and Environmental Sciences. ISSN 1844-489X, 2011, vol. 6, no. 2, pp. 73-84.

HEISLER, G. M. 1986. Energy savings with trees. In Journal of Arboriculture. ISSN 0278-5226, 1986, vol. 12, no. 5, pp. 113-125.

LUHANA, L. - MIDDletON, D. R. - SOKHI, R. S. 2007. Processes and parameters influencing the oxidation of $\mathrm{SO}_{2}$ and $\mathrm{NOx}$ in plumes. Bristol: Environment Agency, 2007. 4 p.

NOWAK, D. J. 1994. Air pollution removal by Chicago's urban forest. In McPherson, E. G., Nowak, D. J., Rowntree, R. A. (eds.). Chicago's urban forest ecosystem: Results of the Chicago urban forest climate project. Radnor: U.S. Dept. of Agriculture, Forest Service, Northeastern Forest Experiment Station, Pennsylvania, pp. 63-81.

PIRINGER, M. - KUKKONEN, J. (eds.). 2002. Mixing height and inversions in urban areas. In Proceedings of the Workshop 3 and 4 October 2001, Toulouse, France. COST Action 715, EUR 20451, Brussels European Commission, 2002, $113 \mathrm{p}$.

QUEROL, X. - ALASTUEY, A. - RUIZ, C. R. - ARTIÑANO, B. - HANSSON, H. C. - HARRISON, R. M. - BURINGH, E. - TEN BRINK, H. M. - LUTZ, M. - BRUCKMANN, P. - STRAEHL, P. - SCHNEIDER, J. 2004. Speciation and origin of $\mathrm{PM}_{10}$ and $\mathrm{PM}_{2.5}$ in selected European cities. In Atmospheric Environment. ISSN 1352-2310, 2004, vol. 38, no. 38, pp. 6547-6555.

QUITTA, A. - REH, W. - SCHLEGEL, M. 2012. Best practice examples from German and European Cities for reducing soot from traffic. Berlin: Deutsche Umwelthilfe, Soot free for the climate. 34 p. [online] Available on: <http://www.cleanair-europe.org/fileadmin/user_upload/redaktion/downloads/ Clean_Air_Publikationen/LIFE_soofree_cities_measures_2012.pdf >.

ROST, J. - HOLST, T. - SAHN, E. - KLINGNER, M. - ANKE, K. - AHRENS, D. - MAYER, H. 2009. Variability of $\mathrm{PM}_{10}$ concentrations dependent on 
meteorological conditions. In International Journal of Environment and Pollution. ISSN 1741-5101, 2009, vol. 36, no. 1-3, pp. 3-18.

RÓZOVÁ Z. et al. 2013. Environmental aspects of the urban environment [Environmentálne aspekty urbanizovaného prostredia]. Nitra: Univerzita Konštantína Filozofa, 2013. 390 p. ISBN 978-80-558-0388-3.

TSAI, Y. I. - CHENG, M. T. 2004. Characterization of chemical species in atmospheric aerosols in a metropolitan basin. In Chemosphere. ISSN 00456535, 2004, vol. 54, no. 8, pp. 1171-1181.

VAZ MONTEIRO, M. - DOICK, K. J. - HANDLEY, P. - PEACE, A. 2016. The impact of greenspace size on the extent of local nocturnal air temperature cooling in London. In Urban Forestry \& Urban Greening. ISSN 1618-8667, 2016, vol. 16, pp. 160-169.

VOS P. E. J. - MAIHEU, B. - VANKERKOM, J. - JANSSEN, S. 2013. Improving local air quality in cities: To treee or not to tree? In Environmental Pollution. ISSN 0269-7491, 2013, vol. 183, pp. 113-122.

WHITEMAN, C. D. - HOCH, S. W. - HOREL, J. D. - CHARLAND, A. 2014. Relationship between particulate air pollution and meteorological variables in Utah's Salt Lake Valley. In Atmospheric Environment. ISSN 1352-2310, 2014, vol. 94, pp. 742-753.

\section{Mgr. Zuzana Pucherová, PhD.}

Department of Ecology and Environmental Science

Faculty of Natural Sciences

Constantine the Philosopher University in Nitra

Tr. A. Hlinku 1, 94974 Nitra, Slovak Republic

E-mail: zpucherova@ukf.sk

Prof. RNDr. Anna Tirpáková, CSc.

†rof. RNDr. Dagmar Markechová, CSc.

Department of Mathematics

Faculty of Natural Sciences

Constantine the Philosopher University in Nitra

Tr. A. Hlinku 1, 94974 Nitra, Slovak Republic

E-mail: atirpakova@ukf.sk,dmarkechova@ukf.sk 